\title{
CDO MARKet IMPlosion AND THE PRICING OF SubPrime Mortgage-BACKED SECURITIES
}

\author{
Yongheng Deng* \\ NUS Business School \\ National University of Singapore \\ Stuart A. Gabriel \\ Anderson School of Management \\ University of California, Los Angeles
}

Anthony B. Sanders

Carey School of Business

Arizona State University

Current Version: December 2008

*Deng is Professor of Finance and Real Estate, National University of Singapore, SDE 1, Level 4, 4 Architecture Dr., Singapore, 117566; Email: ydeng@nus.edu.sg; Gabriel is Arden Realty Chair and Professor of Finance, UCLA Anderson School of Management; 110 Westwood Plaza, Entrepreneurs Hall Suite 412, Los Angeles, CA 90095-1481; Email: stuart.gabriel@anderson.ucla.edu; and Sanders is Herberger Chair of Arizona Heritage and Professor of Finance, W. P. Carey School of Business, P.O. Box 873906, Tempe, AZ 85287-3906; Email: Anthony.B.Sanders@asu.edu. The authors are grateful to Francis Longstaff, Tim Riddiough, and Avanidhar Subrahmanyam for excellent comments and to Minye Zhang, Dawei Tian and Huanghai Li for outstanding research assistance. The authors also thank Mark Flannery and participants in the 2009 AEA session on the subprime crisis for helpful comments. All errors are our responsibility. 


\title{
CDO Market ImPlosion AND The PRICING OF
}

\author{
SUbPrime Mortgage-BACKed SECURITIES
}

\begin{abstract}
The global market for collateralized debt obligations (CDOs) witnessed explosive growth over the 1997-2006 period, as the stock of global issuance expanded from $\$ 300$ billion to almost \$2 trillion. CDO issuance importantly supported the market for subprime mortgage-backed debt, via the re-packaging of those assets into derivative CDO securities. The surge in issuance of subprime mortgage-backed CDOs coincided with a marked tightening in subprime MBS-Treasury spreads, suggesting some measurable effect of this market-completing vehicle on the supply/demand balance and pricing of mortgage-backed securities. In 2007 and in the wake of the implosion in the CDO market, spreads on subprime mortgage-backed securities widened considerably. This research evaluates the effects of the emergence of the CDO market on the pricing of subprime residential mortgage-backed securities. Upon controlling for mortgage option values and other well-established determinants of credit spreads, research indicates that the emergence of the subprime-backed CDO market was associated with a significant tightening of subprime MBS/Treasury yield spreads. Results of VAR and other robustness tests serve to corroborate the results. Research findings suggest the importance of innovations in derivative securities markets to the pricing and related affordability of subprime mortgages. Results similarly indicate that the unexpected closure of the CDO market exerted upward pressure on MBS spreads, and in so doing contributed to changes in the pricing, underwriting and related demise of subprime mortgages.
\end{abstract}

JEL Classification Numbers: R31, G10, G12

Keywords: collateralized debt obligations, subprime crisis, yield spreads on mortgage-backed securities 


\section{INTRODUCTION}

The global market for collateralized debt obligations (CDOs) witnessed explosive growth over the 1997-2006 period, as the stock of global issuance expanded from $\$ 300$ billion to almost $\$ 2$ trillion. CDO issuance importantly supported the market for subprime mortgage-backed securities, via the re-packaging of relatively illiquid assets into derivative $\mathrm{CDO}$ securities. In a stunning market about-face, new issuance of CDOs ceased in 2007, in the wake of implosion and wholesale re-pricing of credit risk in the capital markets. The surge in issuance of real estate-backed CDOs coincided with a marked tightening in subprime MBS-Treasury spreads, suggesting some measurable effect of this market-completing vehicle on the supply/demand balance and pricing of mortgage-backed securities. In 2007 and in the wake of the implosion in the CDO market, spreads on mortgage-backed securities widened considerably.

CDOs are financial structures whereby a set of assets are held in a trust formed as a Special Purpose Vehicle (SPV). A series of tranches with different exposures to the risks of the underlying assets are issued by the trust. A CDO cash-flow structure, for example, allocates the interest and principal payments of the underlying collateral pool of debt instruments to the $\mathrm{CDO}$ tranches. While there are many variations, a cash CDO, for example, is a senior-subordinated structure where the senior CDO debt tranches are paid first, then the mezzanine and lower-subordinated notes. Any remaining cash flow is available to equity. In the CDO structure, a set of assets (such as corporate bonds, CMBS, or residential mortgage-backed securities) can be packaged into claims and sold to investors. ${ }^{1}$

As shown in Table 1, subprime mortgage ABS overwhelmingly dominated other mortgage products (such as prime and second mortgages) as the collateral for CDOs. As shown in Figure 1, issuance of sub-prime asset-backed CDOs moved up fivefold during the first half of the decade-from about $\$ 10$ billion in 2000 to in excess of $\$ 50$ billion in 2006. Coincidentally, spreads to Treasury on subprime MBS-backed CDOs narrowed substantially. Indeed, as evidenced in Figure 1, yield spreads of subprime MBS trended down from a high in excess of 500 basis points in 2000 to about two-fifths that level four years later. Interestingly, as shown in Figure 2, that marked trending down in subprime MBS to Treasury spreads occurred even as subprime MBS issuance was rapidly expanding. Increased demand for subprime MBS product, for purposes of derivative

\footnotetext{
${ }^{1}$ While the rules for distributing the cash flows of the CDO bonds' underlying collateral are relatively straightforward, the valuation of the debt and equity tranches can be complicated. The reason for this complexity is that CDOs often contain a large portfolio of assets and credit exposures with diverse risk profiles (for example, default, loss and recovery patterns) as collateral and there are many possible capital structures from which debt and equity are issued. Unlike those mortgage obligations where prepayment-risk is the dominant focus, in CDO valuation the primary focus is typically on the credit risk. A number of practitioner-oriented papers provide excellent discussions of the CDO market (e.g., Goodman and Fabozzi [2002], Li, Roy, and Skarabot [2004], Roy and Shelton [2004] and Tavakoli [2003]).
} 
securitization via the $\mathrm{CDO}$ vehicle, may have served, all things equal, to depress subprime MBS-Treasury spreads. More recently, during the latter half of 2007, CDO issuance fell dramatically, to $\$ 121$ billion. During that period, the underlying collateral for many CDOs, subprime MBS, began to experience sharp increases in delinquencies and defaults. In the wake of sharp erosion in collateral performance, spreads began to widen markedly in both subprime MBS and CDOs and the issuance of CDOs began to decline. By 2008, issuance of CDOs backed by subprime MBS had ceased.

[Table 1 is about here]

[Figures 1 and 2 are about here]

The rise and fall of the CDO market provides an excellent laboratory to study spreads on credit-sensitive securities. Following previous studies on credit spreads (for example, see Collin-Defresne, Goldstein and Martin [2001], Collin-Defresne and Goldstein [2001] and Chen, Lesmond and Wei [2007]), we examine the credit spreads on CDOs and examine the relationship between the spreads on the underlying collateral and the issuance volume of CDOs. In so doing, we build on the prior literature in evaluating the determinants of yields spreads on mortgage-backed securities.

Much of the research on CDOs has focused on pricing of those derivative securities (for example, see Duffie and Garleanu [2001], Hull and White [2003], Noh [2004], Longstaff, Mithal, and Neis [2005], Ericsson and Renault [2006], Longstaff and Rajan [2006], and Pan and Singleton [2008]). In addition, there has been considerable research on a related topic: correlated default among underlying assets (for example, see Duffee [1998], Duffie, Eckner, Horel, and Saita [2006], Giesecke [2004], Das, Duffie, Kapadia, and Saita [2005] and Giesecke and Goldberg [2005]).

In discussion of the 2008 credit crisis, Gorton [2008] assesses CDO structure and issuance. In particular, Gorton identifies rating-related arbitrage as a primary motivation for CDO issuance. ${ }^{2}$ Further, the opportunity for negative basis trades may have been important to CDO purchase of subprime MBS bonds. ${ }^{3}$ Although recent studies have focused on CDO pricing and issuance, little research has attempted to assess the direct impact of CDO market evolution on spreads in the underlying collateral.

Alternative hypotheses can be put forth regarding the effects of the emergence of the CDO market on the pricing of real estate asset-backed securities. On the one hand, to the extent CDOs confer efficiency benefits as market-completing investment vehicles, institutional demand for CDOs and related derived-demand for asset-backed securities

\footnotetext{
${ }^{2}$ Gorton suggests that by 2005, yield spreads on subordinated subprime MBS tranches were elevated relative of other structured products of similar ratings, providing an opportunity to arbitrage the ratings between the ratings on subprime MBS and on the CDO tranches.

${ }^{3}$ Such negative basis trades could occur to the extent yields on CDO tranches exceed required payment for credit risk protection (in the CDS market). Originators of structured products had an incentive to engage in ratings-related arbitrage to the extent spreads on subprime MBS tranches exceeded those on similarly rated CDO tranches.
} 
may increase. According to this market-completion hypothesis, CDOs may have served to enhance efficiency in the asset-backed securities markets, via the pooling and re-tranching of less liquid and lower-rated subprime MBS into derivative securities that were more tradable. Further, a liquidity premium associated with senior CDO tranches may have reduced the cost of raising capital through tranches below the cost of acquiring the asset pool (see, for example, Greenbaum (1986), DeMarzo and Duffie (1988) and Demarzo (2003)). ${ }^{4,5}$ Assuming less than fully elastic supply of subprime ABS in the capital markets, CDO-related related increments to subprime MBS demand would result in contraction in mortgage-backed security spreads, all things equal.

On the other hand, capitalization and growth of the CDO market could serve to elicit a supply response, in the form of increased sales of subprime securities in the real estate asset-backed securities markets. Those sales might derive from opportunities for improved price execution and/or enhanced outlets for liquification of investor RMBS portfolios. As suggested by Greenbaum and Thakor (1987), the advent of new securities markets allows financial intermediaries to remove assets from their balance sheets and reduce other costs of holding debt. All things equal, this supply-shift hypothesis would serve to depress subprime asset-backed security prices and concomitantly result in wider MBS-Treasury spreads.

Indeed, prior research has suggested the importance of sector-specific supply/demand imbalances in the determination of yield spreads. Collin-Dufresne, Goldstein, and Martin (2001) show that monthly credit spread changes are largely driven by supply/demand shocks that are independent of both credit-risk factors and standard proxies for liquidity. Duffie and Singleton (1999), controlling for credit-risk and liquidity factors, find that swap market supply/demand shocks drive unexplained changes in swap rates. Similarly, supply/demand shocks appear important to analyses of Ginnie Mae yield spreads (Boudoukh et al (1997)). Evidence also points to the role of supply/demand imbalances in the determination of other residential mortgage yield

\footnotetext{
${ }^{4}$ DeMarzo and Duffie (1998) and DeMarzo (2003) build liquidity-based models of tranching. In those models, the security issuer may possess private information regarding security payoff that may cause illiquidity. However, the senior tranches (low risk tranches) are less sensitive to the (CDO) issuer's private information, and thus may enjoy greater liquidity than the underlying collateral.

${ }^{5}$ On the other hand, DeMarzo (2005) shows that for an informed intermediary, pure pooling and sales of assets from the pool is inferior to selling assets separately. This is because asset pooling eliminates the intermediary's option regarding how aggressively to market each asset and thus can reduce the payoff. This is called the "information destruction effect". However, there can be an offsetting "risk diversification effect" of pooling and tranching - in that the intermediary can create lower-risk derivative securities from the asset pool, and such securities are less sensitive to the intermediary's private information and accordingly can be more attractively priced to the investor. In the case of CDOs, gains from risk diversification were expected to exceed losses from information destruction, such that on net pooling and tranching facilitated higher gains than individual asset sales.
} 
spreads (see, for example, Bradley, Gabriel, and Wohar (1995) and Lehnert, Passmore, and Sherlund (2008)).

Alternatively, according to a simple shell game hypothesis, elevated demand for subprime-backed MBS might have been driven by inaccurate CDO underwriting or ratings, mis-information, mis-representations, or lack of full understanding of the risks of the CDO vehicle. Some combination of those factors could serve to explain tighter spreads to Treasury on ABS. An alternative asymmetric information hypothesis suggests that CDO issuers may possess private asymmetric information regarding asset returns, and engage in related price discrimination via tranching to maximize profits (Oldfield (2000) or use such pooling and tranching methodologies to diversity risk (DeMarzo (2005)). ${ }^{6}$

Finally, one might posit a production efficiency hypothesis, whereby specialization and vertical disintegration of such functions as ABS securitization, ownership and servicing, would serve to enhance production efficiency and in so doing decrease ABS production costs. This hypothesis derives from well-known work by Greenbaum (1988) and Hess and Smith (1988) which posits gains from specialization of activity in each step of the intermediation and securitization function. Here we would similarly anticipate some contraction in ABS-Treasury spreads.

In this paper, we undertake empirical assessment of the effects of CDO issuance on the pricing of subprime MBS. We employ various empirical specifications to identify CDO issuance effects. Initial results of Granger Causality Wald Tests (see Table 2) allow rejection of the null hypothesis that issuance of subprime-backed CDOs does not Granger Cause changes in subprime/Treasury spreads. ${ }^{7}$ Given those results, we undertake parametric estimation of GMM models using the Newey-West Kernal for error correction. Those models specify and control for well-established pricing influences in the determination of MBS/Treasury spreads. Finally, we provide results and simulation of VAR models.

[Table 2 is about here]

Results of the empirical analysis suggest that factors associated with the termination risks of the underlying subprime residential mortgage contracts, including

\footnotetext{
${ }^{6}$ Oldfield (2000) argues that tranching may allow security issuers to further enhance returns via price discrimination. Assuming that the demand functions for various derivative products are imperfectly price elastic, Oldfield (2000) explains that the security issuer seeks private information about investor demand via the security design and sales process, and uses that information to segment the market and price discriminate among different sets of customers. In the case of CDOs, the price discrimination could be facilitated via the re-bundling of the pool and the selling the different tranches at different prices.

7 Table 2 reports the Granger Causality Wald Test statistics. The $p$-value $<5 \%$ allows rejection of the null-hypothesis that the natural $\log$ of issuance of subprime-backed CDOs does not Granger Cause changes in subprime/Treasury spreads.
} 
interest-rate volatility, the term structure of interest rates, and proxies for credit risk in the macro-economy, importantly affect the magnitude of mortgage security/Treasury spreads. Further, subprime MBS to Treasury spreads evidence only limited sensitivity to returns and related return volatility among alternative asset classes, notably including those of equity markets. Finally, holding constant those factors, research indicates that the emergence of the CDO market was associated with a significant contraction in subprime mortgage security to Treasury yield spreads. Results of VAR models suggest that a one standard deviation negative shock to $\ln$ CDO issuance over a period of 3-, 6-, and 9 months, results in a widening of subprime MBS/Treasury yield spreads by $110 \mathrm{bps}, 150$ bps, and 170 bps, respectively. Further, findings suggest that a one standard deviation positive shock in subprime MBS/Treasury spreads lasting for 3 to 9 months leads to further widening in spreads by up to $1,000 \mathrm{bps}$.

Note further that CDO pricing effects likely were passed back to borrowers in the primary market. In that regard, interest rates faced by subprime borrowers rose markedly in the wake of the 2007 collapse of CDO markets and related reductions in the valuation of subprime mortgage pools. Accordingly, our results provide the first systematic evidence linking derivative $\mathrm{CDO}$ markets to the pricing of sub-prime mortgages.

The remainder of this paper is organized as follows. Section II discusses the influence of CDOs on the pricing of subprime residential mortgage-backed securities. Section III describes the data used in the study and presents the empirical model, and Section IV presents the empirical findings and simulation results. Section V summarizes the results and provides concluding remarks.

\section{THE ROLE OF CDOS IN THE DETERMINATION OF SUBPRIME MBS YIELD SPREADS}

The termination risks of mortgage-backed securities differ substantially from those of U.S. Treasuries. Treasury obligations provide a full faith and credit U.S. government guarantee of timely repayment of principal and interest. In marked contrast, the cash flows and hence pricing of mortgage-backed securities reflect regularities associated with borrower exercise of mortgage put and call options. Those borrower options are typically written into the mortgage contract; in well-functioning markets, option valuations are embedded in the mortgage-treasury rate spread. In the case of the mortgage put option, mortgage borrowers may put the mortgage back to the lender in the case of default. Also, call option exercise is often permitted in the case of residential mortgages. Indeed, the inadequacy of both underwriting and pricing of default risk over past years has been fundamental to the sub-prime crisis. ${ }^{8}$

\footnotetext{
${ }^{8}$ In subprime residential debt markets, the MBS issued by investment banks were backed by private mortgage insurance and other forms of credit enhancement rather than the full faith and credit of the U.S. government.
} 
Frequent borrower exercise of the mortgage call option, in the form of mortgage prepayment, was evidenced over the period of analysis. ${ }^{9}$ Indeed, prepayment risks should vary with expectations regarding the future path of interest rates. Also, higher levels of interest rate volatility suggest higher call option values and elevated risks of mortgage termination. Those risks should be priced into higher mortgage spreads over Treasuries. However, this effect is mitigated somewhat in environments with steeper yield curves, as this term structure suggests that interest rate declines associated with volatility will be more muted, thereby implying diminished termination risk premia for seasoned mortgage product.

Spreads between mortgage and Treasury securities also may reflect variability among asset classes in risk-adjusted returns. As such, changes in investor asset allocation among mortgage and corporate debt, equity, and government bonds could markedly affect the pricing of mortgage-backed securities. For example, higher returns to equities might result in investor portfolio re-allocation to that asset class, resulting in damped demand for and elevated premia among securitized mortgage product. Of course, elevated equity returns likely would have less influence on portfolio asset allocation to the extent the higher equity returns are accompanied by elevated return volatility.

Finally, numerous hypotheses can be brought to bear as regards the effects of rise and fall of the CDO market on the pricing of subprime MBS. As suggested above, the market-completion, shell game, specialization and production, and asymmetric information hypotheses all point to a tightening of subprime MBS/Treasury spreads in the wake of the emergence of the CDO market. In contrast, the supply-shift hypothesis suggests that growing capitalization of the CDO vehicle may have elicited a MBS supply response and hence a widening of spreads to Treasuries. While the relative magnitudes of those influences are difficult to entangle, we test below for the influence of CDO issuance in the determination of subprime MBS/Treasury spreads, controlling for the relative magnitude of $\mathrm{CDO}$ to subprime MBS issuance and other well-established pricing determinants.

\section{A. Theoretical Determinants of Mortgage Bond Spreads}

Slope of the Treasury Yield Curve: There exists substantial evidence on the role of the term structure in the determination of mortgage bond spreads (see, for example, Bradley, Gabriel and Wohar (1995), Ambrose and Sanders (2003), Titman,

\footnotetext{
9 The recent housing boom years witnessed a secular increase in residential mortgage prepayment speeds, owing to technological innovation and reductions in the costs of mortgage re-finance, enhanced mortgage product offerings, improved borrower knowledge of and ease of loan qualification, and substantial downward adjustment in mortgage interest rates subsequent to the 2001 recession. In the case of subprime mortgages, conditional on adequate house price appreciation, refinancing was common over relatively short time horizons.
} 
Tompaidis and Tsyplakov (2005)). As is widely-appreciated, an increase in the slope of the yield curve suggests some future strengthening in economic activity. As such, a steeper yield curve imparts a higher probability of a short rate increase. A steeper yield curve reduces the likelihood that the mortgage call option will be in the money, so as to reduce prepayment risk and the related call option premium. Accordingly, increases in the slope of the Treasury yield curve should have a negative impact on the mortgage-backed security-Treasury spread.

Volatility: Mortgage put and call option values increase with interest rate volatility. In fact, in a contingent claims framework, the debt claim has elements similar to a short position on a put option. Mortgage bond spreads should increase with volatility. This prediction is intuitive and is well established in the literature; increased interest rate volatility implies increases in the probability of prepayment and default.

Credit Risk: Fama and French (1989) find that credit spreads widen when economic conditions are weak. We use the interest rate spread between corporate bonds rated Aaa and Baa to proxy such economy-wide credit risk. In the current application, we hypothesize that the put option embedded in the mortgage contract should vary directly with economy-wide credit risk and the market price of risk. The credit spread proxy has been previously applied to proxy mortgage default risk [see, for example, Duca and Rosenthal (1989), Bradley, Wohar and Gabriel (1995)].

Alternative Assets Returns: As evidenced in Kwan (1996) and Collin-Dufresne, Goldstein, and Martin (2001), returns to alternative asset classes, notably including equity returns, may affect the demand for and yields on fixed income securities. Similar to those papers, we include excess return in the S\&P 500 over the 3-month constant maturity Treasury yield as well as a measure of volatility of S\&P 500 excess returns to proxy returns on alternative equity investment classes.

\section{B. CDO Market Evolution: Determinants related to Market Capitalization and Supply/Demand Imbalances}

Subprime CDO Issuance/Subprime MBS Issuance: The analysis controls for the magnitude of subprime $\mathrm{CDO}$ monthly issuance relative to that of underlying subprime mortgage-backed securities. To the extent subprime MBS issuance declines due to adverse collateral performance, but $\mathrm{CDO}$ issuance does not fall at a similar rate, we would expect the ratio of subprime CDO to subprime MBS issuance to exert upward pressure on spreads.

Subprime MBS CDO Issuance: Controlling for evolution in the ratio of subprime CDO to subprime MBS issuance, positive deviations in subprime CDO issuance (whether owing to market completion, specialization and production efficiency, asymmetric information, or other effects) should work to increase demand for underlying subprime securitized product. All things equal, increases in derived demand for 
underlying securitized product should result in some tightening of subprime MBS-Treasury spreads.

Table 3 provides description of the explanatory variables and summarizes the predicted sign of the changes in subprime/Treasury spreads in response to the changes in the underlying determinants.

[Table 3 is about here]

\section{EMPIRICAL MODEL AND DATA}

We estimate the following reduced form model. ${ }^{10}$

$$
\begin{aligned}
\Delta\left(r_{B_{t}}-r_{N_{t}}\right)= & \alpha+\beta_{1} \Delta \text { Slope }_{t}+\beta_{2} \Delta \text { Vol }_{\text {CMT }}+\beta_{3} \Delta \text { Slope }_{t} \times \Delta V_{\text {Vol }} \text { CMT }_{t}+\beta_{4} \Delta\left(r_{\text {Aaa }_{t}}-r_{\text {Baa }_{t}}\right) \\
& +\beta_{5} \Delta S \& P_{t}+\beta_{6} \Delta S \& P_{t} \times \Delta V_{\text {ol }} \text { S\&P }_{t}+\beta_{7} \ln \left(C D O \text { IsS }_{t}\right)+\beta_{8} \frac{\text { CDO_IsS }}{\text { Section_IsS }_{t}}+\mu_{t}
\end{aligned}
$$

In the above equation, the dependent variable is measured as the basis point differential in spreads between the relevant mortgage and Treasury securities. All models are estimated in first differences using the GMM. The Newey-West kernel approach is used for error correction. The independent variables in the estimating equations are as described above. Of central interest to this analysis is the indicator of monthly issuance of subprime-backed collateralized debt obligations; we estimate those effects over two sample periods.

\section{Data}

Our sample covers the period from January 1997 to August 2006. The descriptive statistics for our data is presented in Table 4 . In addition to the mean, maximum, minimum and standard deviation for each variable, we also perform a unit root test both with and without a trend.

${ }^{10}$ A similar specification can be found in Collin-Defresne, Goldstein and Martin (2001) in their empirical estimation of the determinants of changes in credit spreads.

11 The unit root test statistics reported in Table 4 indicate that many of the time series measured in levels have a unit root. As discussed by Granger and Newbold (1974), stochastic trends (which have a unit root) can lead two time series to appear to be related when in actuality they are not. To avoid potential estimation bias due to spurious correlation, we use the first difference of all the time series except for $\ln$ of CDO issuance and the ratio of subprime CDO to subprime MBS issuance in our regressions. Results of further tests indicate that the first difference in the time series variables are significant at the 1 percent level in our unit root tests, with the exception 
[Table 4 is about here]

Data sources and variable construction are as follows:

Yield Spreads on Asset-Backed Bonds: Subprime residential MBS yields are obtained from TrueStandings Securities. The subprime rates are the weighted average of all residential mortgages classified as subprime by LoanPerformance. Subprime mortgage-backed bond yield spreads are then defined as the difference between the yield of the bond and the associated yield of the constant maturity 10-year Treasury.

Slope of the Treasury Yield Curve: The Treasury yield data-yields on the 10-year Constant Maturity Treasury (CMT) and spread between the 10-year CMT and the 3-month CMT - are obtained from the Federal Reserve Economic Data website at the Federal Reserve Bank of St. Louis. These data are published as monthly averages of their respective series. We interpret this variable as both an indicator of expectations of future short rates as well as an indicator of overall status of the economy.

Volatility: Our measure of interest rate volatility is the annualized standard deviation of the $\log$ differences in daily yields on the 10-year Treasury. We also compute the interaction of the yield curve and volatility terms.

Credit Risk: The monthly time-series on corporate bonds rates Aaa and Baa are obtained from Moodys Investors Services. This variable is defined as the yield on corporate bonds rated Baa minus the yield on corporate bonds rated Aaa.

Equity Market Returns: The monthly S\&P 500 return series including dividends and price changes is obtained from Datastream. We use the S\&P 500 return series to measure both equity market returns and related volatility in that return.

\section{CDO Market Evolution}

Subprime CDO Issuance: We obtain information on CDO issuance from ABAlert.com. The ABAlert.com database contains information on the initial terms of all rated issuance of asset-backed securities, mortgage-backed issues and collateralized debt obligations. ${ }^{12}$ The database provides the information on CDO issuance by all the

of the mortgage-backed security-Treasury yield spreads, $y_{t}$, which is significant at the 10 percent level. As a robustness check to address the potential estimation bias with a marginally significant yield spreads process, $y_{t}$, we also test our model by replacing yield spreads with the ratio of yield spreads to the 10 -year Treasury yield, $y_{t}^{\prime}$, such that $y_{t}^{\prime}=X_{t} \beta+\mu_{t}$, where $y_{t}^{\prime}$ is significant at 1 percent level in our unit root test.

12 The primary objective of the ABAlert.com database is to identify the primary participants in each transaction. This database does not include information on pricing or other 
major players, including Wells Fargo, ABN AMRO/ LaSalle Bank, J.P. Morgan Chase, and the like. The ABAlert.com database assigns each issue to one of five categories: Public ABS, Private ABS, MBS, Non-US ABS and CDOs. To compute our subprime CDO issuance series, we aggregate the dollar volume of those CDOs labeled as subprime CDOs by ABAlert. In order to qualify as a subprime CDO, ABAlert required that at least 75 percent of underlying collateral was comprised of subprime MBS. ${ }^{13}$ The full data timeframe for subprime CDO issuance is from January 1997 to August 2006.

Subprime CDO Issuance/Subprime MBS Issuance: Ratio of Subprime MBS-backed CDO issuance to subprime MBS issuance. Subprime residential MBS issuance is obtained from TrueStandings Securities.

\section{ESTIMATION AND SIMULATION RESULTS}

\section{A. Static Analysis}

Results from the static analysis based on GMM estimation of the subprime asset-backed security/Treasury spreads equations are summarized in Table 5. Table 5 contains estimates for Model 1: 1997-2006 and Model 2: 2001-2006. As evidenced in Table 5, the estimated coefficients are of expected sign. For example, in Model 1, our measure of interest rate volatility, the change in the annualized standard deviation of the $\log$ differences in daily yields on the ten-year Treasury, is positive and highly significant in the determination of changes in MBS pricing. Overall, results coincide with priors that higher levels of interest rate volatility are positively priced into mortgage-Treasury spreads. As expected, the term reflecting changes in the slope of the Treasury yield curve enters the mortgage/Treasury spread equations with a negative and significant coefficient, as a steeper yield curve reduces the likelihood that the mortgage call option will come into the money, so as to reduce prepayment risk and the related call option premium. Note that the interaction of the slope of yield curve and volatility change terms enters the model with the expected negative coefficient, suggesting significantly diminished volatility-related widening of the MBS/Treasury spread as the yield curve steepens. Finally, in Model 1, while the default risk proxy and the alternative asset return have the expected positive effect on changes in the MBS spread, neither coefficient is precisely estimated.

[Table 5 is about here]

Also as anticipated our proxy for the ratio of subprime CDO to subprime ABS issuance is positive and significant throughout. As subprime MBS issuance slows down

tranche-specific information. The database captures only the terms of each issue as of its pricing date, so it doesn't reflect subsequent events, such as paydowns and rating changes. (For further information, see: http://abalert.com/NewPages/Index.cfm?Article ID=41086).

${ }^{13}$ In computing the dollar volume of CDO issuance, we exclude issuance related to bank loans (CLOs). 
due to adverse performance in the underlying subprime mortgage collateral, continued CDO issuance relative to a declining subprime MBS asset base should lead to an increase in spreads.

Finally, all things equal, research findings suggest that the rapid growth in CDO issuance has been significant to the pricing of subprime residential mortgage-backed securities. As evidenced in Table 5, the CDO issuance coefficient is negative and statistically significant; further, as expected, the estimated magnitude of the CDO issuance effect approximately triples in value in the 2001-2006 period of explosive growth in $\mathrm{CDO}$ market capitalization. ${ }^{14}$ Furthermore, the estimated magnitude of the ratio of subprime $\mathrm{CDO}$ issuance to subprime mortgage issuance increased threefold during the 2001-2006 period indicating the increase in CDO issuance to the growth of subprime ABS issuance.

\section{B. Vector Autoregression and Impulse Responses}

To further explore the dynamic relationship between subprime/Treasury yield spreads and the underlying time series variables, we adopt a structural vector autoregression (VAR) model to conduct the dynamic analysis. Our primary focus is to test how pricing of subprime mortgage-backed securities changes in response to shocks in the issuance of subprime-backed CDOs. We estimate the VAR model with changes in subprime/Treasury yield spread and natural log of issuance of subprime-backed CDOs as endogenous variables, whereas the remaining control variables in equation (1) are treated as exogenous variables.

Column 1 of Table 6 reports the estimated impulse responses of the subprime/Treasury spread to the natural log of issuance of subprime-backed CDOs based on the full sample period of 1997.01 to 2006.08. Findings indicate significant and negative impulse responses of the subprime MBS/Treasury spread to CDO issuance lagged by two months. Results also indicate a marginally significant and positive impulse response to $\mathrm{CDO}$ issuance lagged one month and a less significant and negative impulse response to the $\mathrm{CDO}$ issuance in current month, perhaps reflecting a mean-reverting effect in the impulse response estimates (correction due to over-reaction in the previous month's impulse responses).. Column 2 of Table 6 reports the impulse response of CDO issuance, i.e., an endogenous feedback of the dynamic process. The significant and positive coefficients for CDO issuance lagged by one month, two months and three months, respectively, suggest that momentum associated with positive supply shocks in CDO issuance might lead to further compression in the subprime

${ }^{14}$ We also test the model using data on CMBS tranched spreads to swaps. All things equal, research findings suggest that the rapid growth in commercial real estate-backed CDO issuance has been significant to the pricing of CMBS. The CDO issuance coefficient is negative and statistically significant throughout; further, as expected, the estimated magnitude of the CDO issuance coefficient increases monotonically with reductions in tranche rating. 
MBS/Treasury spreads. ${ }^{15}$ While the estimated coefficients for the exogenous variables have the expected signs, most are smaller in magnitude relative to those reported in Table 5. Overall, VAR results indicate the importance of dynamic analysis of CDO issuance effects in the determination of subprime mortgage-backed securities spreads.

[Table 6 is about here]

\section{Simulations}

Finally, we use the results from Table 6 to simulate the impulse responses associated with changes in subprime mortgage-backed security pricing associated with 3-month, 6-month, and 9-month cumulative shocks to the issuance of subprime-backed CDOs. Using the full sample $(1997.01$ - 2006.08) estimates, Figure 3 reports the simulated impulse responses in the subprime MBS/Treasury yield spreads. Results indicate that a one standard deviation negative shock in $\ln$ CDO issuance lasting 3 months, 6 months, and 9 months, results in a widening of the subprime MBS/Treasury yield spread of $110 \mathrm{bps}, 150 \mathrm{bps}$, and $170 \mathrm{bps}$, respectively. Further, findings reported in Figure 4 suggest that a one standard deviation positive shock in subprime MBS/Treasury spreads lasting for 3 to 9 months leads to further widening in spreads by up to 1,000 bps. Figures 5 and 6 report the simulated impulse responses of subprime MBS/Treasury yield spreads based on estimates from the $2001.01-2006.08$ sub-sample. Results are largely robust to the change in estimation period.

[Figures 3 to 6 are about here]

\section{CONCLUSION}

This research evaluates effects of the emergence of the CDO market on the pricing of subprime residential mortgage-backed securities. In so doing, it applies high-frequency time-series to evaluate the determinants of yield spreads of subprime residential mortgage-backed securities (RMBS) to comparable-maturity Treasury bonds. Empirical tests suggest that factors associated with the termination risks of the underlying residential mortgage contracts, including proxies for mortgage prepayment and credit risk, importantly affect the magnitude of MBS/Treasury spreads. Spreads on mortgage-backed securities also appear sensitive to returns and related return volatility among alternative asset classes. Finally, holding constant new issuance of mortgage-backed securities and other well-established proxies for mortgage option values, research indicates that the emergence of the CDO market was associated with a

15 The last two columns in Table 6 report the estimated impulse responses associated with a sub-sample covering the 2001.02 to 2006.08 period. While the qualitative results remain similar to those reported above, the coefficient estimates are less significant, perhaps due in part to the limited set of data points in the shorter sampling period. 
significant tightening of subprime RMBS/Treasury yield spreads. Results of VAR and other robustness tests serve to corroborate the results. Further, VAR findings indicate substantial widening of spreads in the wake of sustained shocks to CDO issuance. Research findings suggest the importance of innovations in derivative securities markets to the pricing and related affordability of subprime mortgages. Results similarly indicate that the unexpected closure of the CDO market exerted upward pressure on MBS spreads, and in so doing contributed to changes in the pricing, underwriting and related demise of subprime mortgages. 


\section{REFERENCES}

Ambrose, B. and A. Sanders, 2003, Commercial Mortgage (CMBS) Default and Prepayment Analysis, Journal of Real Estate Finance and Economics, 26

Bradley, Michael, Stuart Gabriel, and Mark Wohar, "The Thrift Crisis, Mortgage Credit Intermediation, and Housing Activity", 1995, Journal of Money, Credit, and Banking, 27, 476 497.

Collin-Dufresne, Pierre, Robert S. Goldstein and J. Spencer Martin, 2001, The Determinants of Credit Spread Changes, Journal of Finance, 56, 2177-2207.

Das, S., D. Duffie, N. Kapadia, and L. Saita, 2006, Common Failings: How Corporate Defaults are Correlated, Journal of Finance, forthcoming.

DeMarzo, Peter, 2003, Portfolio Liquidation and Security Design with Private Information, Stanford University working paper.

DeMarzo, Peter, 2005, The Pooling and Tranching of Securities: A Model of Informed Intermediation, Review of Financial Studies, 18: 1-35

DeMarzo, Peter and Darrell Duffie, 1999, A Liquidity-Based Model of Security Design, Econometrica, 67: 65-99

Duca, John and S. Rosenthal, 1989, "An Empirical Test of Credit Rationing in the Mortgage Market", Journal of Urban Economics

Duffee, G., 1998, The Relation Between Treasury Yields and Corporate Bond Yield Spreads, Journal of Finance 23, 2225-2241

Duffie, D., A. Eckner, G. Horel, and L. Saita, 2006, Frailty Correlated Default, Working Paper, Stanford University

Duffie, D., and N. Garleanu, 2001, Risk and Valuation of Collateralized Debt Obligations, Financial Analysts Journal 57 (January/February), 41-59

Duffie, D., and K. Singleton, 1999, Modeling Term Structures of Defaultable Bonds, Review of Financial Studies 12, 687-720

Ericsson Jan and Olivier Renault, 2006, Liquidity and Credit Risk, Journal of Finance, 61, 2219-2250.

Fama, Eugene and Kenneth French, 1989, Business Conditions and Expected Returns on Stocks and Bonds, Journal of Financial Economics 25, 23-49. 
Giesecke, K., 2004, Correlated Default With Incomplete Information, Journal of Banking and Finance 28, 1521-1545

Giesecke, K., and L. Goldberg, 2005, A Top Down Approach to Multi-Name Credit, Working Paper, Cornell University

Goodman, Laurie and Fabozzi, Frank, 2002, Collateralized Debt Obligations Structures and Analysis, John Wiley and Sons, Hoboken, New Jersey

Gorton, Gary, 2008, The Subprime Panic, European Financial Management

Granger, C.W.J. and P. Newbold, 1974, Spurious Regression in Econometrics, Journal of Econometrics, 16, 121-130

Greenbaum, Stuart I., 1986, Securitization, Asset Quality and Regulatory Reform, BRC working paper no. 147, Northweatern University, Evanston, IL.

Greenbaum, Stuart I. and Anjan V. Thakor, 1987, Bank Funding Modes: Securitization versus Deposits, Journal of Banking and Finance 11, 379-401.

Hess, Alan C. and Clifford W. Smith Jr., 1988, Elements of Mortgage Securitization, Journal of Real Estate Finance and Economics 1, 331-346.

Hull, J., and A. White, 2003, Valuation of a CDO and a n-th to Default CDS Without Monte Carlo Simulation, Working Paper, University of Toronto

Kwan, Simon H., 1996. Firm-specific information and the correlation between individual stocks and bonds, Journal of Financial Economics 40, 63-80.

Lehnert, Andreas, Wayne Passmore, and Shane M. Sherlund, 2008, GSEs, Mortgage Rates, and Secondary Market Activities, Journal of Real Estate Finance and Economics 36, 343-363.

Li, D., R. Roy, and J. Skarabot, 2004, A Primer on Single-Tranche CDOs, Citigroup Global Structured Credit Research, Citigroup, New York, NY

Longstaff, F., S. Mithal, and E. Neis, 2005, Corporate Yield Spreads: Default Risk or Liquidity? New Evidence from the Credit Default Swap Market, Journal of Finance 60, 2213-2253

Longstaff, Francis A. and Arvind Rajan, 2006, An Empirical Analysis of the Pricing of Collateralized Debt Obligations, working paper, UCLA.

Noh, J., 2004. "Estimation of Credit and Default Spreads: An Application to CDO Valuation," Econometric Society 2004 Far Eastern Meetings 
Oldfield, George S., 2000, Making Markets for Structured Mortgage Derivatives, Journal of Financial Economics 57, 445-471.

Pan, J., and K. Singleton, 2008, "Default and Recovery Implicit in the Term Structure of Sovereign CDS Spreads", Journal of Finance, 63, 2345-2384.

Roy, R., and D. Shelton, 2004, Trading Credit Tranches, Citigroup Global Structure Credit Research, Citigroup, New York, New York

Tavakoli, Janet M., 2003, Collateralized Debt Obligations \& Structured Fiance: New Developments in Cash \& Synthetic Securitization, Wiley Finance, Wiley, John \& Sons, Incorporated.

Titman, Sheridan, Stathis Tompaidis and Sergey Tsyplakov, 2004, Determinants of Credit Spreads in Commercial Mortgages, Real Estate Economics 33(4), 711-738. 
Table 1: Residential Mortgage Deals in 420 ABS CDOs

\begin{tabular}{|l|c|c|c|c|c|}
\hline Number of Deals by Vintage and Mortgage Loan Type \\
\hline Vintage & Subprime & Alt-A & Seconds & Prime & Total \\
\hline $\mathbf{2 0 0 3}$ & 215 & 63 & 7 & 144 & 429 \\
\hline $\mathbf{2 0 0 4}$ & 371 & 252 & 25 & 188 & 836 \\
\hline $\mathbf{2 0 0 5}$ & 488 & 452 & 62 & 209 & 1,211 \\
\hline $\mathbf{2 0 0 6}$ & 522 & 487 & 69 & 142 & 1,220 \\
\hline $\mathbf{2 0 0 7}$ & 150 & 113 & 21 & 28 & 312 \\
\hline Total & 1,746 & 1,367 & 184 & 711 & 4,008 \\
\hline
\end{tabular}

Source: UBS, "Mortgage and ABS CDO Losses," December 13, 2007 
Table 2: Granger Causality Wald Test

\begin{tabular}{lcc}
\hline \hline Null Hypothesis & F-Statistic & P-Vaule \\
\hline Ln CDO Issuance Does Not Granger Cause $\Delta$ Subprime Spread & 3.1555 & $0.0279^{*}$ \\
$\Delta$ Subprime Spread Does Not Granger Cause Ln CDO Issuance & 0.1696 & 0.9167
\end{tabular}

Note: * indicates rejection of the null hypothesis at the 5 percent level.

Table 3. Explanatory Variables and Expected Signs of the Coefficients of the Basic Model:

$$
\begin{aligned}
\Delta\left(r_{B_{t}}-r_{N_{t}}\right)= & \alpha+\beta_{1} \Delta \text { Slope }_{t}+\beta_{2} \Delta \text { Vol }_{\text {CMT }}+\beta_{3} \Delta \text { Slope }_{t} \times \Delta V_{\text {Vol }} \text { CMT }_{t}+\beta_{4} \Delta\left(r_{\text {Aaa }_{t}}-r_{\text {Baa }_{t}}\right) \\
& +\beta_{5} \Delta S \& P_{t}+\beta_{6} \Delta S \& P_{t} \times \Delta V V_{S \& P_{t}}+\beta_{7} \ln \left(C D C_{-} \text {IsS }_{t}\right)+\beta_{8} \frac{\text { CDO_IsS }}{\text { Section_IsS }_{t}}+\mu_{t}
\end{aligned}
$$

\begin{tabular}{|c|c|c|}
\hline Variable & Description & $\begin{array}{l}\text { Predicted } \\
\text { Sign }\end{array}$ \\
\hline$\Delta\left(r_{B_{t}}-r_{N_{t}}\right)$ & $\begin{array}{l}\text { Change in spread between subprime MBS yield and } 10 \text {-year } \\
\text { CMT yield (dependant variable) }\end{array}$ & \\
\hline$\Delta$ Slope & $\begin{array}{l}\text { Change in spread between 10-year CMT and 3-month CMT } \\
\text { yields }\end{array}$ & - \\
\hline$\Delta \mathrm{Vol}_{\mathrm{CMT}}$ & Change in 10 -year CMT volatility & + \\
\hline$\Delta$ Slope $\times \Delta V_{\text {OMI }}$ & Interaction of change in slope and change in volatility & - \\
\hline$\Delta\left(r_{\text {Ааa }}-r_{\text {Ваa }}\right)$ & $\begin{array}{l}\text { Change in default risk measured by spread in composite yields on } \\
\text { corporate Aaa and Baa bonds rated by Moody's }\end{array}$ & + \\
\hline$\Delta S \& P$ & $\begin{array}{l}\text { Change in excess return on S\&P } 500 \text { (dividend included) index } \\
\text { over the 3-month CMT }\end{array}$ & + \\
\hline$\Delta S \& P \times V o l_{S \& P}$ & Interaction of change in S\&P 500 return and S\&P 500 Volatility & - \\
\hline $\operatorname{Ln}\left(C D O_{-} I s s\right)$ & Natural log of dollar volume of subprime CDO issuance & - \\
\hline$\frac{\text { CDO_Iss }}{\text { Section Iss }}$ & $\begin{array}{l}\text { Ratio of subprime CDO issuance over subprime residential MBS } \\
\text { issuance }\end{array}$ & + \\
\hline
\end{tabular}


Table 4: Descriptive Statistics and Unit Root Test

\begin{tabular}{|c|c|c|c|c|c|c|}
\hline & \multicolumn{4}{|c|}{ Descriptive statistics } & \multicolumn{2}{|c|}{ Unit root test (P-Value) } \\
\hline & mean & maximum & minimum & Std. Dev. & w/o trend & $\mathrm{w} /$ trend \\
\hline Subprime Spread & 3.8868 & 5.4080 & 2.2030 & 0.6986 & 0.3899 & 0.2365 \\
\hline Slope & 1.4410 & 3.6800 & -0.7000 & 1.2137 & 0.6302 & 0.9326 \\
\hline $\mathrm{Vol}_{\mathrm{CMT}}$ & 0.2182 & 0.4550 & 0.0758 & 0.0814 & $0.0065^{*}$ & $0.0334 *$ \\
\hline Slope $\times \Delta$ Vol $_{\mathrm{CMT}}$ & 0.3679 & 1.3220 & -0.1300 & 0.3764 & 0.5076 & 0.8290 \\
\hline Default Risk & 0.0086 & 0.0141 & 0.0055 & 0.0022 & 0.1812 & 0.4197 \\
\hline S\&P & 0.06363 & 1.4619 & -2.7889 & 0.8078 & $0.0000 *$ & $0.0000^{*}$ \\
\hline $\mathrm{S} \& \mathrm{P} \times \Delta \mathrm{Vol}_{\mathrm{S} \& \mathrm{P}}$ & -0.0024 & 0.5480 & -1.1215 & 0.2344 & $0.0000 *$ & $0.0000^{*}$ \\
\hline $\operatorname{Ln}\left(C D O \_I s s\right)$ & 1.4573 & 3.0978 & -1.6663 & 1.0660 & 0.2279 & 0.2430 \\
\hline CDO_Iss/Section_Iss & 4.3237 & 5.4679 & 2.9113 & 0.6893 & 0.2833 & 0.9934 \\
\hline
\end{tabular}

Note: The last two columns give the Phillips-Perron test of the null hypotheses that the indicated series have a unit root. * indicates statistical significance at the 5 percent level. 
Table 5. GMM Estimations of Subprime Yield to Treasury Spreads on Subprime CDO Issuance

$$
\begin{aligned}
& \Delta\left(r_{B_{t}}-r_{N_{t}}\right)=\alpha+\beta_{1} \Delta \text { Slope }_{t}+\beta_{2} \Delta \operatorname{Vol}_{\text {CMT }}+\beta_{3} \Delta \text { Slope }_{t} \times \Delta \operatorname{Vol}_{\text {CMT }}+\beta_{4} \Delta\left(r_{\text {Aaa }_{t}}-r_{\text {Baa }_{t}}\right) \\
& +\beta_{5} \Delta S \& P_{t}+\beta_{6} \Delta S \& P_{t} \times \Delta V l_{S \& P_{t}}+\beta_{7} \ln \left(C D O \_I s s_{t}\right)+\beta_{8} \frac{C D O \_I s s_{t}}{\text { Section_Iss }_{t}}+\mu_{t}
\end{aligned}
$$

\begin{tabular}{|c|c|c|}
\hline & $\begin{array}{c}\text { Model } 1 \\
(1997 \sim 2006)\end{array}$ & $\begin{array}{c}\text { Model } 2 \\
(2001 \sim 2006)\end{array}$ \\
\hline Constant & $\begin{array}{c}-0.0494 \\
(-1.51)\end{array}$ & $\begin{array}{l}-0.0813 \\
(-1.03)\end{array}$ \\
\hline$\Delta$ Slope & $\begin{array}{l}-0.7567 \\
(-10.03)\end{array}$ & $\begin{array}{l}-0.8086 \\
(-7.83)\end{array}$ \\
\hline$\Delta \mathrm{Vol}_{\mathrm{CMT}}$ & $\begin{array}{l}1.1789 \\
(3.76)\end{array}$ & $\begin{array}{l}0.6377 \\
(0.84)\end{array}$ \\
\hline$\Delta$ Slope $\times \Delta \mathrm{Vol}_{\mathrm{CMT}}$ & $\begin{array}{l}-0.4918 \\
(-4.20)\end{array}$ & $\begin{array}{l}-0.3160 \\
(-1.22)\end{array}$ \\
\hline$\Delta$ Default Risk & $\begin{array}{l}0.1712 \\
(1.33)\end{array}$ & $\begin{array}{l}0.1018 \\
(0.69)\end{array}$ \\
\hline$\Delta \mathrm{S} \& \mathrm{P}$ & $\begin{array}{l}0.0295 \\
(0.82)\end{array}$ & $\begin{array}{l}0.0199 \\
(0.45)\end{array}$ \\
\hline$\Delta \mathrm{S} \& \mathrm{P} \times \Delta \mathrm{Vol}_{\mathrm{S} \& \mathrm{P}}$ & $\begin{array}{l}-0.1371 \\
(-1.11)\end{array}$ & $\begin{array}{l}-0.1940 \\
(-1.58)\end{array}$ \\
\hline Ln of Subprime CDO Issuance & $\begin{array}{l}-0.0457 \\
(-2.88)\end{array}$ & $\begin{array}{l}-0.1295 \\
(-3.21)\end{array}$ \\
\hline $\begin{array}{l}\text { Ratio of Subprime CDO Issuance } \\
\text { to Subprime Mortgage Issuance }\end{array}$ & $\begin{array}{l}1.4117 \\
(2.49)\end{array}$ & $\begin{array}{l}4.4379 \\
(4.62)\end{array}$ \\
\hline Number of Observations & 113 & 67 \\
\hline Adjusted $\mathrm{R}^{2}$ & 0.5610 & 0.5319 \\
\hline
\end{tabular}

Note:

1. All models are estimated by GMM approach. Newey-West Kernel is used for error corrections. Dependent variables are the first difference of spreads between the yield on subprime mortgage debt and the 10-year Treasury CMT. Model 1 is estimated based on full sample of data from 1997.1 to 2006.8. Model 2 is estimated based on a sub sample of data from 2001.2 to 2006.8 .

2. $\Delta$ Slope is change in spread between the 10-year CMT and the 3-month $\mathrm{CMT}$. $\Delta \mathrm{Vol}_{\mathrm{CMT}}$ is change in the volatility of 10 -year CMT. $\Delta$ Default Risk is measured by the change in the spread between the yields on long term Aaa and Baa corporate bonds. $\triangle \mathrm{S} \& \mathrm{P}$ is change in excess return of S\&P 500 (dividend included) index over the 3-month CMT. $\Delta V_{\text {ool }} \& \mathrm{P}$ is change in the volatility of excess return of S\&P 500 index over the 3-month CMT. Subprime CDO issuance is measured in billions of dollars.

3. t-statistics are in parenthesis. 
Table 6: the coefficient estimates of the impulse response models

$$
\left\{\begin{array}{l}
x_{t}=\alpha_{10}+\beta_{12} y_{t}+\sum_{i=1}^{3} \delta_{1 i} x_{t-i}+\sum_{j=1}^{3} \varphi_{1 j} y_{t-j}+\gamma B+u_{x t} \\
y_{t}=\alpha_{20}+\sum_{i=1}^{3} \delta_{2 i} x_{t-i}+\sum_{j=1}^{3} \varphi_{2 j} y_{t-j}+\gamma B+u_{y t}
\end{array}\right.
$$

\begin{tabular}{|c|c|c|c|c|}
\hline \multirow{2}{*}{$\begin{array}{l}\text { Variable } \\
\text { Constant }\end{array}$} & \multicolumn{2}{|c|}{$\begin{array}{l}\Delta \text { Sub Spead Ln CDO Iss } \\
(1997.01-2006.08)\end{array}$} & \multicolumn{2}{|c|}{$\begin{array}{c}\Delta \text { Sub Spead Ln CDO Is } \\
(2001.02-2006.08)\end{array}$} \\
\hline & $\begin{array}{c}0.0137 \\
(0.3596)\end{array}$ & $\begin{array}{l}-0.6674 \\
(-8.4744)\end{array}$ & $\begin{array}{l}-0.0997 \\
(-0.8943)\end{array}$ & $\begin{array}{l}-0.5794 \\
(-2.8604)\end{array}$ \\
\hline$\Delta$ Slope $(\mathrm{t})$ & $\begin{array}{l}-0.5691 \\
(-8.7505)\end{array}$ & $\begin{array}{l}-0.2228 \\
(-1.6624)\end{array}$ & $\begin{array}{l}-0.6285 \\
(-5.7241)\end{array}$ & $\begin{array}{l}-0.4260 \\
(-2.1349)\end{array}$ \\
\hline$\Delta \operatorname{Vol}_{\mathrm{CMT}}(\mathrm{t})$ & $\begin{array}{c}1.5386 \\
(4.6273)\end{array}$ & $\begin{array}{l}-0.1976 \\
(-0.2884)\end{array}$ & $\begin{array}{c}0.4433 \\
(0.5856)\end{array}$ & $\begin{array}{l}-0.8440 \\
(-0.6135)\end{array}$ \\
\hline$\Delta$ Slope $\times \Delta \operatorname{Vol}_{\mathrm{CMT}}(\mathrm{t})$ & $\begin{array}{c}-0.5912 \\
(-3.7823)\end{array}$ & $\begin{array}{c}0.1153 \\
(0.3580)\end{array}$ & $\begin{array}{c}-0.1962 \\
(-0.6850)\end{array}$ & $\begin{array}{c}0.4265 \\
(0.8194)\end{array}$ \\
\hline$\Delta$ Default Risk (t) & $\begin{array}{c}0.1161 \\
(0.6004)\end{array}$ & $\begin{array}{c}0.2054 \\
(0.5153)\end{array}$ & $\begin{array}{l}-0.0250 \\
(-0.1035)\end{array}$ & $\begin{array}{c}0.0022 \\
(0.0049)\end{array}$ \\
\hline$\Delta \mathrm{S} \& \mathrm{P}(\mathrm{t})$ & $\begin{array}{c}0.0032 \\
(0.0943)\end{array}$ & $\begin{array}{l}-0.0807 \\
(-1.1678)\end{array}$ & $\begin{array}{l}-0.0124 \\
(-0.2404)\end{array}$ & $\begin{array}{c}0.0177 \\
(0.1891)\end{array}$ \\
\hline$\Delta \mathrm{S} \& \mathrm{P} \times \Delta \mathrm{Vol}_{\mathrm{S} \& \mathrm{P}}(\mathrm{t})$ & $\begin{array}{c}-0.0211 \\
(-0.1921)\end{array}$ & $\begin{array}{c}0.2576 \\
(1.1359)\end{array}$ & $\begin{array}{c}-0.0066 \\
(-0.0416)\end{array}$ & $\begin{array}{c}-0.0172 \\
(-0.0600)\end{array}$ \\
\hline Ratio of CDO Iss ( $t$ ) & $\begin{array}{c}0.4741 \\
(0.9699)\end{array}$ & $\begin{array}{c}15.9770 \\
(15.8619)\end{array}$ & $\begin{array}{c}1.8023 \\
(2.3201)\end{array}$ & $\begin{array}{r}14.1596 \\
(10.029)\end{array}$ \\
\hline Ln of CDO Iss (t) & $\begin{array}{l}-0.1060 \\
(-1.1221)\end{array}$ & - & $\begin{array}{l}-0.1353 \\
(-1.1076)\end{array}$ & - \\
\hline$\Delta$ Sub Spread (t-1) & $\begin{array}{c}0.0324 \\
(0.4698)\end{array}$ & $\begin{array}{l}-0.0618 \\
(-0.4348)\end{array}$ & $\begin{array}{c}0.0511 \\
(0.5132)\end{array}$ & $\begin{array}{l}-0.2242 \\
(-1.2384)\end{array}$ \\
\hline Ln of CDO Iss (t-1) & $\begin{array}{c}0.0437 \\
(1.9480)\end{array}$ & $\begin{array}{c}0.1805 \\
(3.9034)\end{array}$ & $\begin{array}{c}0.0414 \\
(0.9681)\end{array}$ & $\begin{array}{c}0.2483 \\
(3.1979)\end{array}$ \\
\hline$\Delta$ Sub Spread (t-2) & $\begin{array}{c}-0.1653 \\
(-2.6635)\end{array}$ & $\begin{array}{c}-0.1460 \\
(-1.1412)\end{array}$ & $\begin{array}{c}-0.2642 \\
(-3.1549)\end{array}$ & $\begin{array}{c}-0.0890 \\
(-0.5851)\end{array}$ \\
\hline Ln of CDO Iss ( $t-2)$ & $\begin{array}{l}-0.0727 \\
(-3.4741)\end{array}$ & $\begin{array}{c}0.2693 \\
(6.2476)\end{array}$ & $\begin{array}{l}-0.0560 \\
(-1.4131)\end{array}$ & $\begin{array}{c}0.2481 \\
(3.4447)\end{array}$ \\
\hline
\end{tabular}


Table 6: the coefficient estimates of the impulse response models (continued)

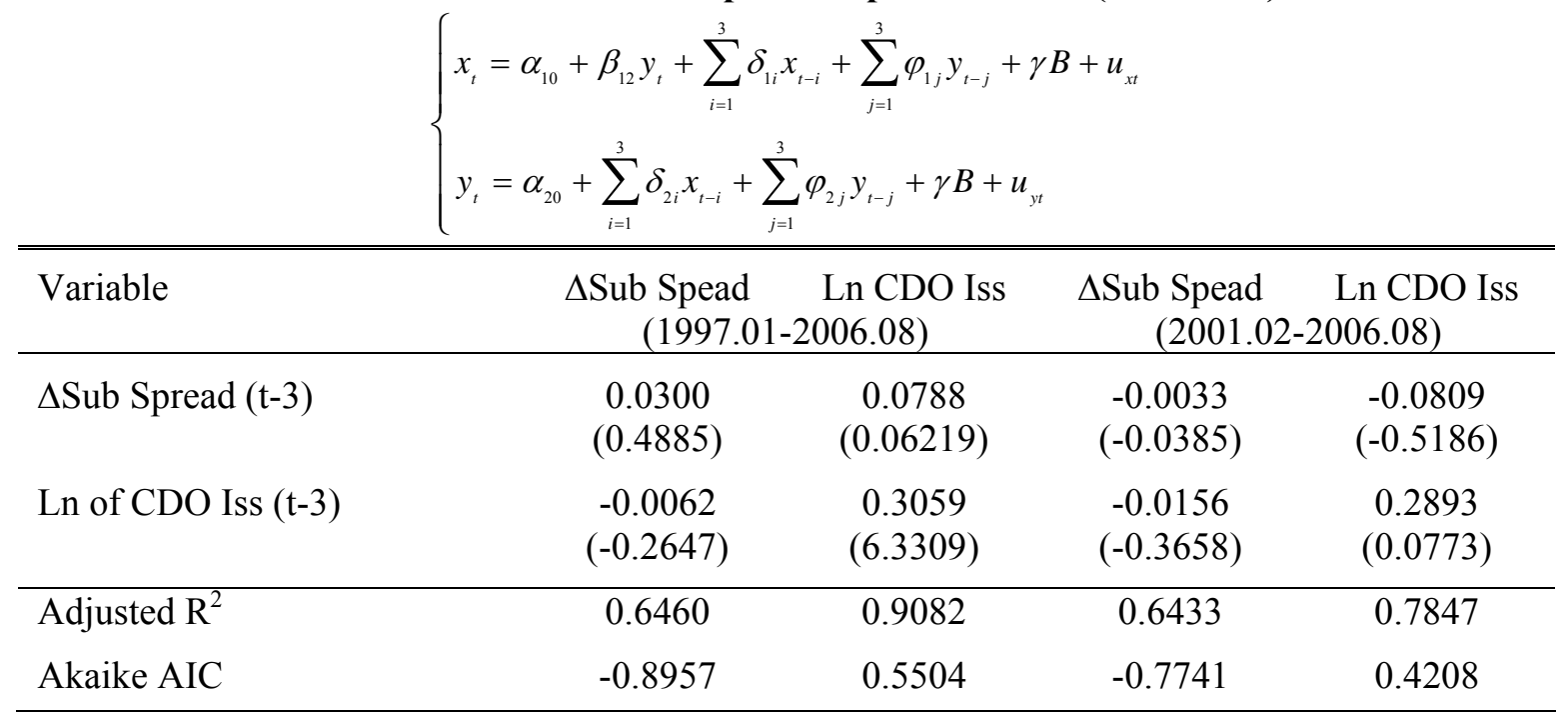

Note:

1. All models are estimated using $\operatorname{VAR}(3)$, where $x$ and $y$ are endogenous variables and $B$ is a set of exogeneous variables. Endogenous variables include Subprime spread and Ln of CDO Issuance; exogenous variables include $\Delta \mathrm{Vol}_{\mathrm{CMT}} ; \Delta$ Slope; $\Delta$ Slope $\times \Delta \mathrm{Vol}_{\mathrm{CMT}} ; \Delta \mathrm{S} \& \mathrm{P} \times \Delta \mathrm{Vol}_{\mathrm{S} \& \mathrm{P}} ; \Delta \mathrm{S} \& \mathrm{P} ; \Delta$ Default Risk; Ratio of CDO Issuance to Subprime Issuance.

2.t-statistics are in parenthesis. 
Figure 1: Yield Spread vs. Subprime CDO Issuance

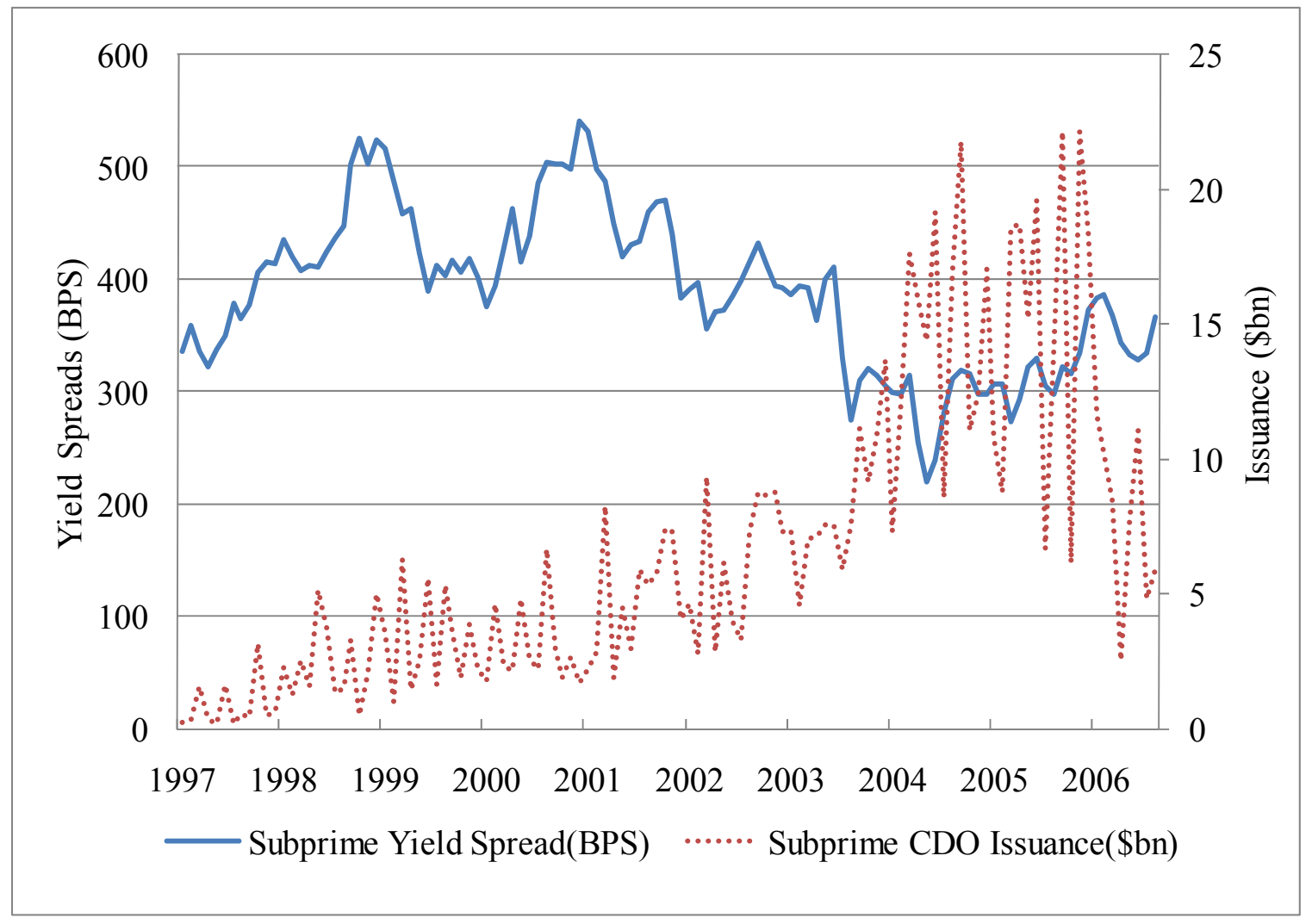


Figure 2: Yield Spread vs. Subprime MBS Issuance

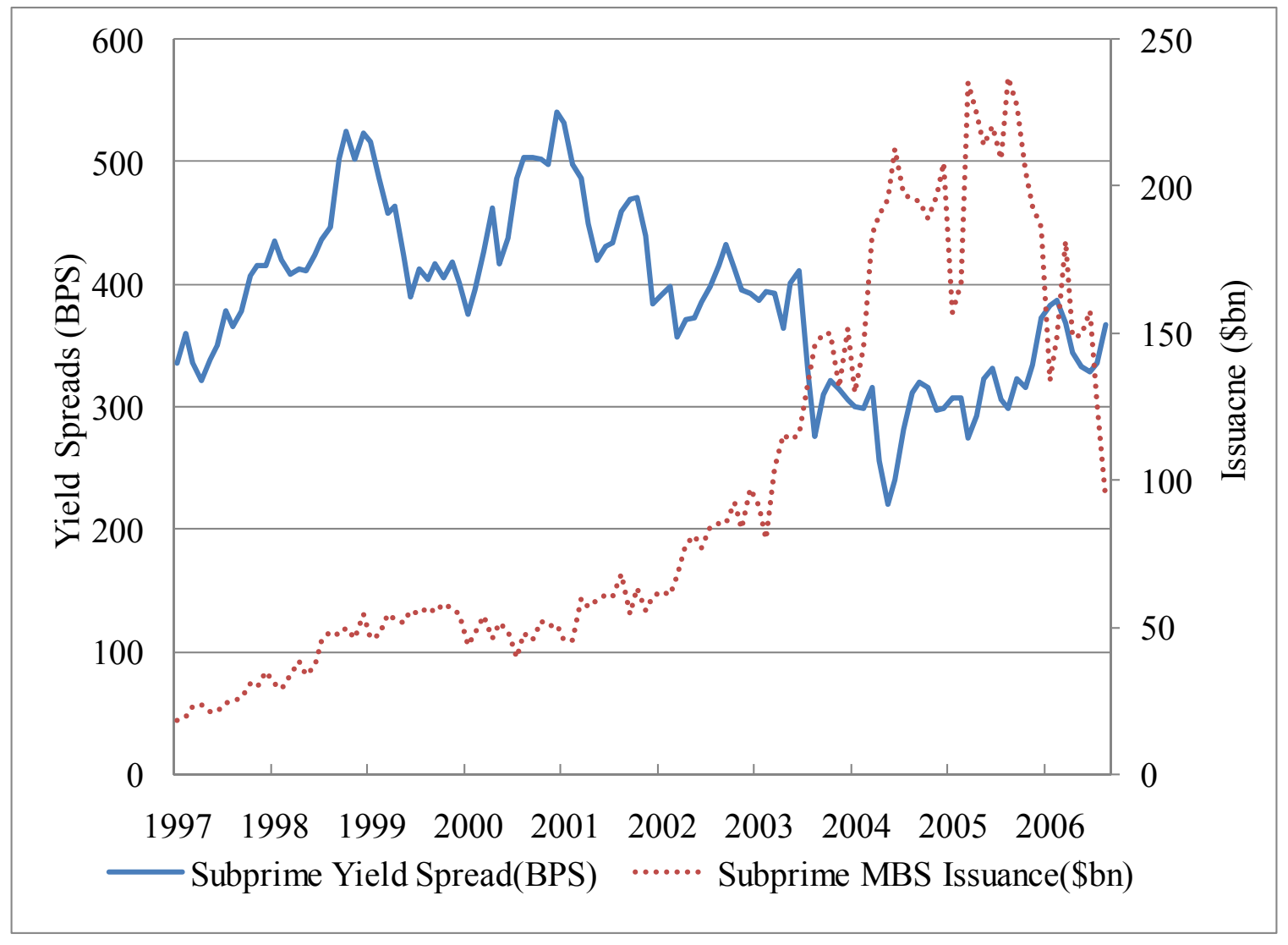


Figure 3: Cumulative Impulse Response of $\Delta$ Subprime Yield Spread to Ln CDO Issuance (1997.01-2006.08)

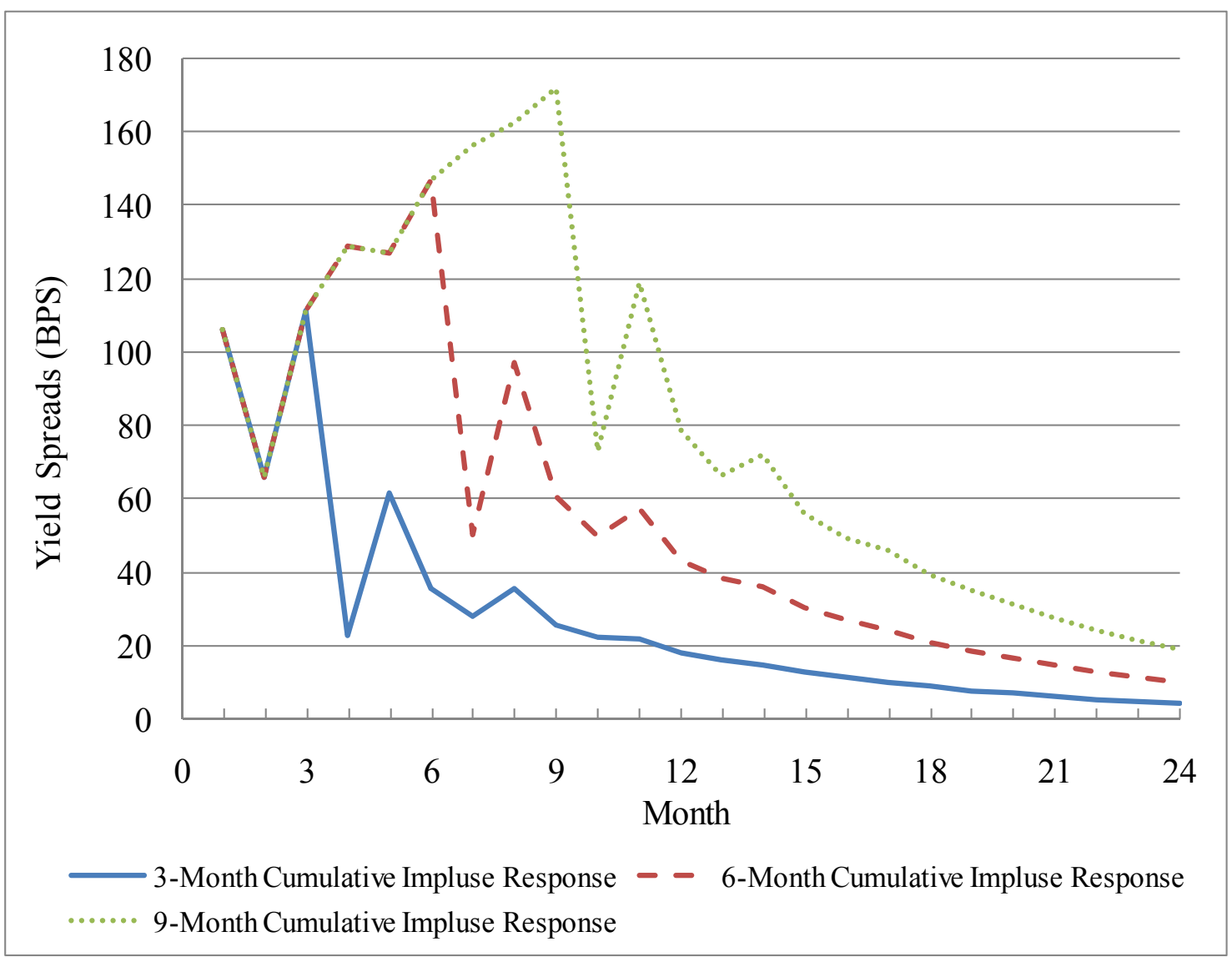


Figure 4: Cumulative Impulse Response of $\Delta$ Subprime Yield Spread to $\Delta$ Subprime Yield Spread (1997.01-2006.08)

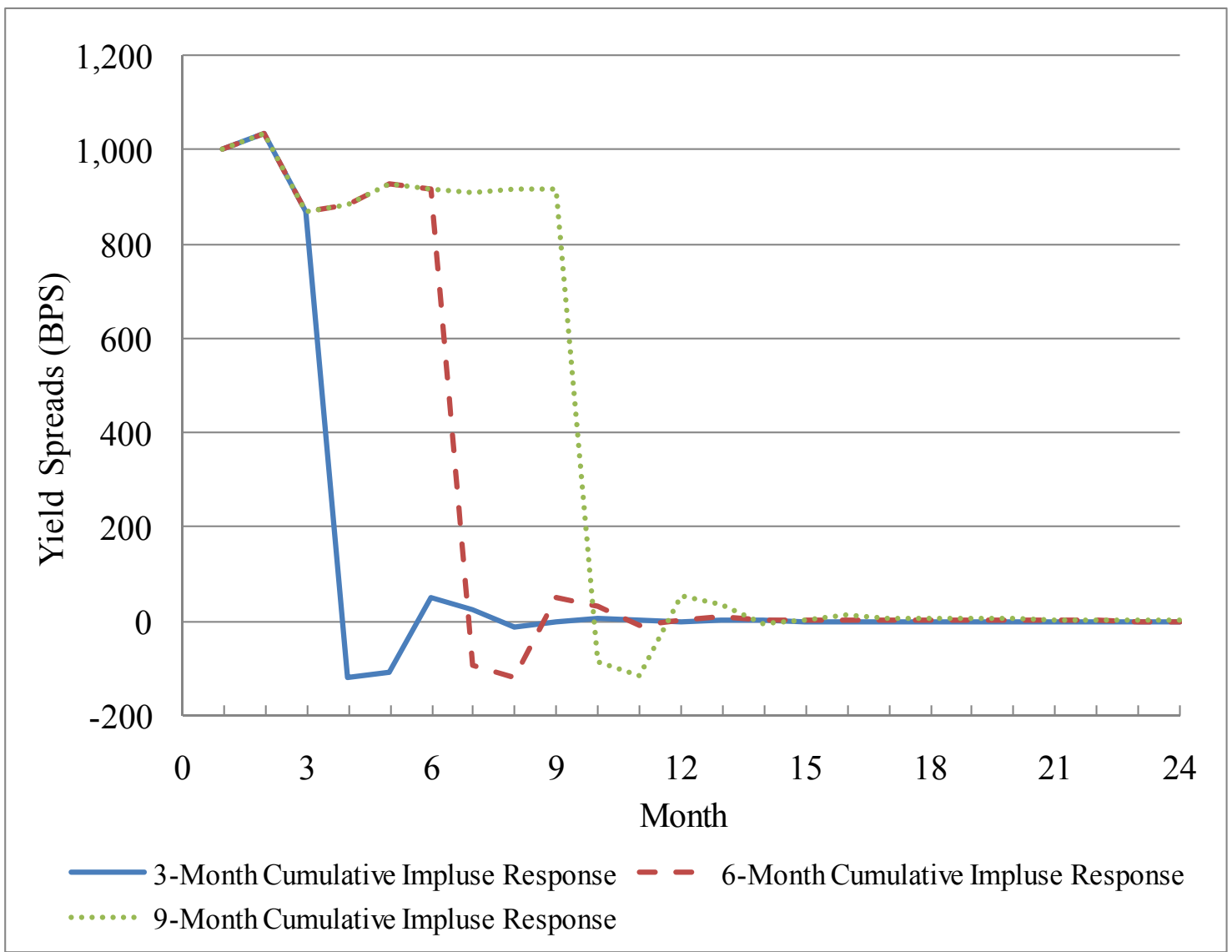


Figure 5: Cumulative Impulse Response of $\Delta$ Subprime Yield Spread to Ln CDO Issuance (2001.02-2006.08)

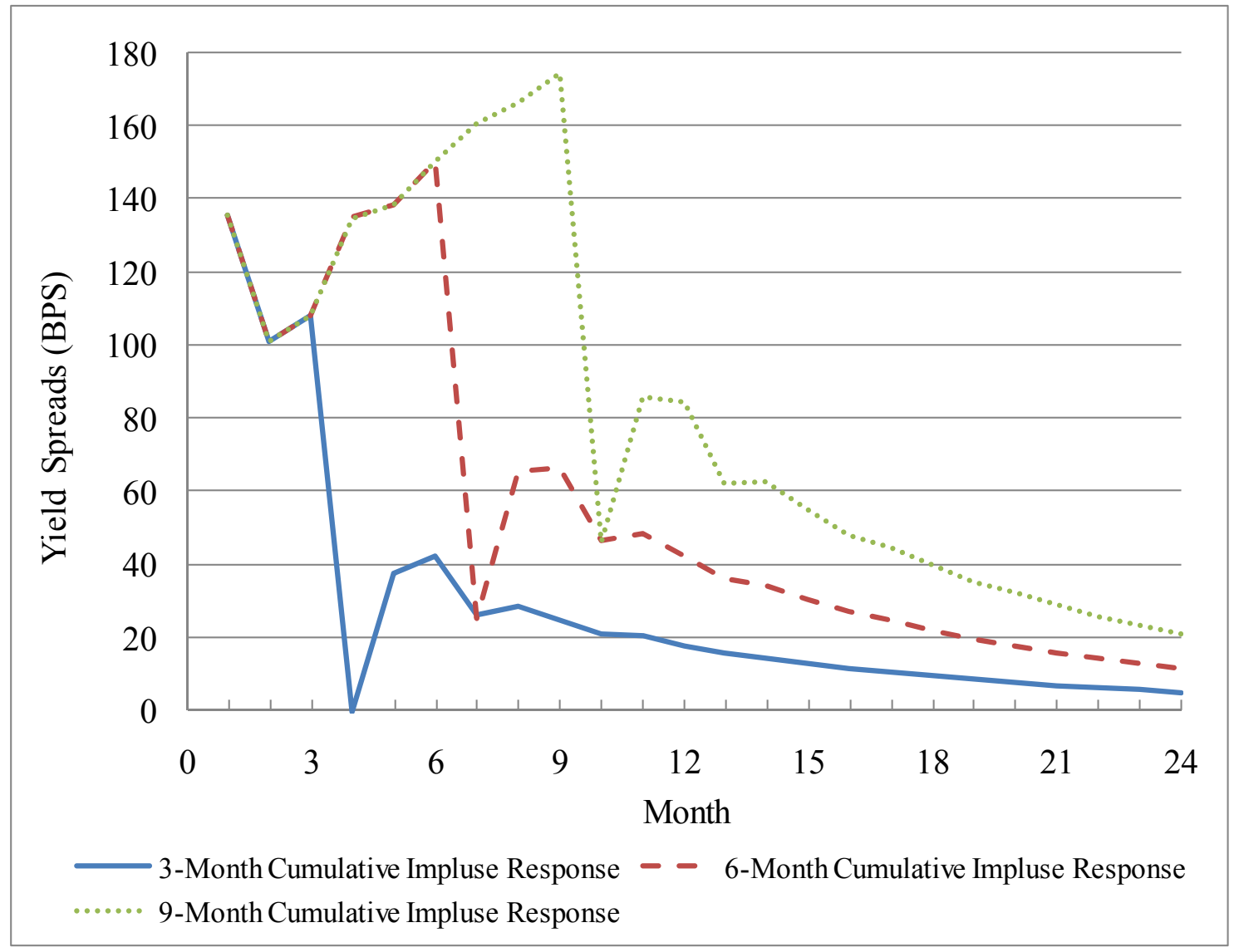


Figure 6: Cumulative Impulse Response of $\Delta$ Subprime Yield Spread to $\Delta$ Subprime Yield Spread (2001.02-2006.08)

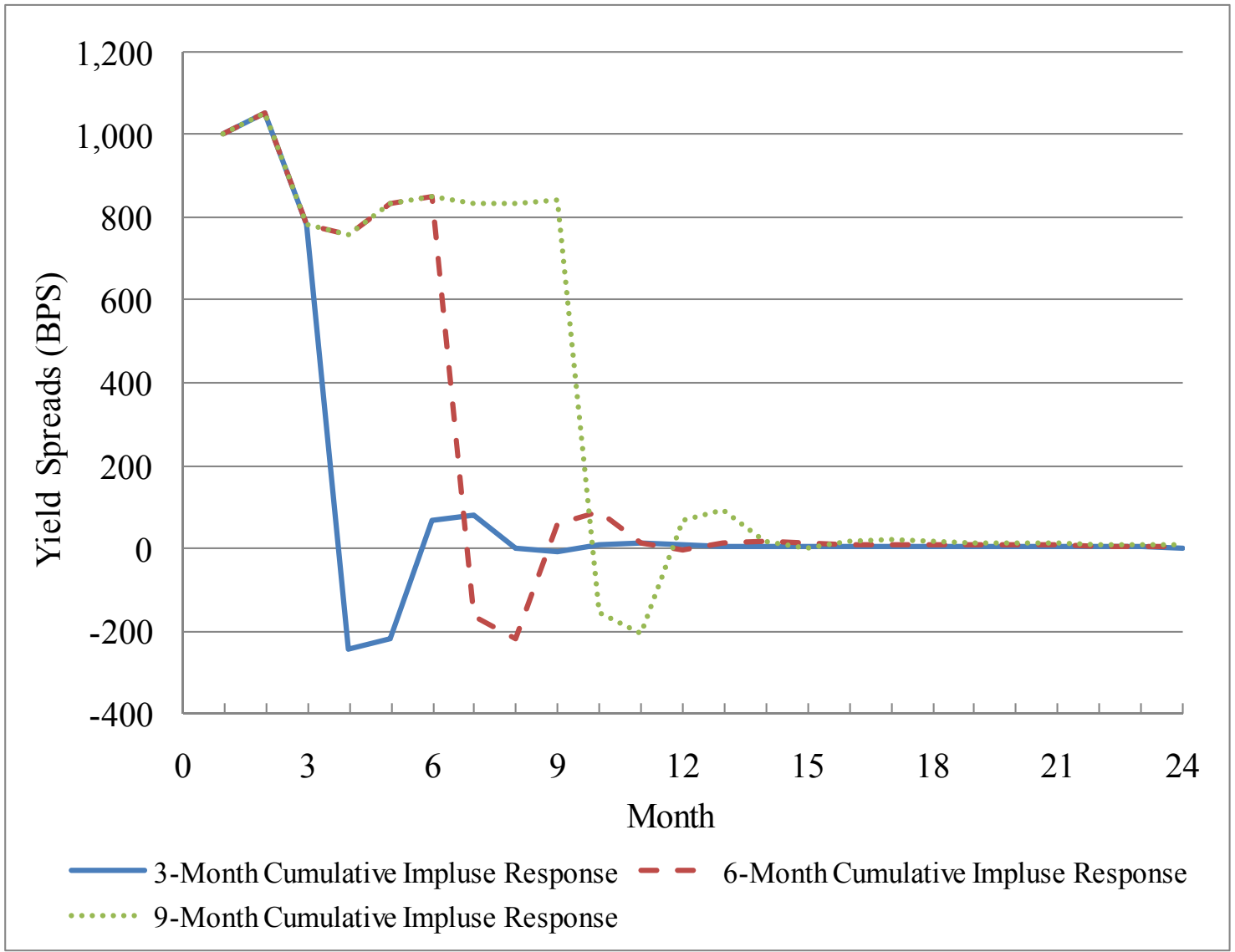

